fiducial lines on this standard. This supposition is supported by the results for Yard No. VI, on which the lines are perhaps a little better still, and for which over the period 1922-63 consistency of behaviour in the region of about $0.1 \mu \mathrm{m}$, or about 1 part in 10 million, has been experienced.

The early history of Yard No. VI is one of rapid shortening. This standard was initially in extremely close agreement with Yard No. 1, but it is now $7 \mu \mathrm{m}$ (about 2.5 ten-thousandths of an inch) shorter than No. 1 and $10 \mu \mathrm{m}(0.0004 \mathrm{in}$.) shorter than originally. But for a slight discontinuity between 1912 and 1922 (due perhaps to a minor shock) it might have been even shorter now.

The results on Yards 2,3 and 5 have been much more irregular. Those for Yard No. 3 are particularly erratic, and it is interesting that this standard has been kept with the Pound No. 2 which has also been a little unstable 4 Both the Yards 3 and 5 changed considerably in relation to Yard No. 1 between 1892 and 1902 . Incidentally, while Yard No. 1 may have decreased similarly to No. VI (Fig. 2) in its early days, the spread of the values at any given time would be unaffected if this were allowed for. Broadly, Fig. 2 shows that Yard No. 2 has agreed with Yard No. 1 very closely throughout their existence.

In this article the present values of the yard standards, formerly the Imperial Standard Yard and its Parliamen- tary copies, have been presented against the background of an indication of the history of the yard from its earliest days to the present time. Details of the recent determinations will be published shortly elsewhere. It is a far ery from grains of barley to wave-lengths of a particular kind of light as emitted under closely defined conditions; whereas the earliest yard standards were probably not consistent to better than 1 part in 1,000 the present definition of the yard admits of a precision, through wavelengths, of 1 part in $10^{8}$ (ref. 8). The present definition is likely to meet the requirements for accurate measurements for a long time to come. For how long, it would be rash to hazard.

This article is published by permission of the Director of the National Physical Laboratory.

1 The Statute for Measuring Land, 33 Edward I, Stat. 6, A,D. 1305 (in Latin) 2 Airy, G. B., Phil, Trans, Roy, Soc, 147, 621 (1857).

${ }^{3}$ Barrell, H., Proc. Roy. Soc., A, 186, 164 (1946).

"Report on the Comparisons of the Parliamentary Copies of the Imperial Standards with the Imperial Standard Yard and the Imperial Standart Pound and with each other during the Years 1947 to 1948 (H.M.S.O. London, 1950).

${ }^{5}$ Report on the Comparisons of the Parliamentary Copies of the Imperial
Standards with each other during the Year 1957 (H.M.S.O., London, 1958). Standards with each other during the Year 1957 (H.M.S.O., London, 1958). - Sears, J. E., Johnson, W. H., and Jolly, H. L. P., Phil. Trans. Roy. Sor. 227, 281 (1928).

"Hart, K. H., and Baird, K. M., Canad. J. Phys., 39, 781 (1961).

" Barrell, H., Nature, 189, 195 (1961).

\title{
OBITUARIES
}

\section{Dr. Graham P. DuShane}

Graham Phillips DuShane, editor of Science during 195̃6-62, died of a heart attack on July 19, 1963. Earlier in the spring he had been in hospital for five weeks recuperating from a mild coronary attack. Recovery was apparently thoroughly satisfactory; the intervening period had been one of partial rest and gradual resumption of his duties; at the time of his death he was on a leisurely trip from his home in Nashville, Tennessee, to Palo Alto, California. The fatal attack thus came as an unexpected shock to family and friends and brought to an untimely end DuShane's career as experimental embryologist, teacher, editor and university administrator.

Graham DuShane was born in South Bend, Indiana, on July 20, 1910, son of Donald and Harriette Graham (McLelland) DuShane. He received the Bachelor of Arts Degree from Wabash College in 1930, which awarded him an honorary LL.D. degree in 1958. From Wabash College he went to Yale University to become a student under Prof. Ross Harrison, through whose guidance he received the Ph.D. degree in 1934. The summer of 1931 was spent in Munich and the year 1934-35 as a research associate at the University of Iowa. Receipt of one of the highly coveted National Research Council fellowships allowed him to spend the following year at Stanford University. During 1936-46 as instructor, assistant professor and then associate professor of biology in the University of Chicago he continued his research in experimental embryology of the amphibians, the development of pigmentation and the nervous system, and the induction of melanin by strange ectoderms. His most significant research contribution was the finding in amphibians that cells migrate outward from the developing neural tube to become pigment cells in the ectoderm.

At the University of Chicago he also developed a reputation as an outstandingly good teacher, and was honoured by the University in 1945 with an award for excellence in undergraduate teaching. In 1946 he accepted a professorship at Stanford University, where his research interests were primarily carried out by graduate students, while his own time was largely devoted to developing and supervising the excellent general biology course which was taken by most Stanford undergraduates and to the revision of the undergraduate curriculum in biology that he left as a legacy to Stanford when he became editor of Science.

At the beginning of 1956 he joined the staff of the American Association for the Advancement of Science as editor of Science and The Scientific Monthly. The six and a half years of his editorship were years of steady and major improvement in the quality, size and circulation of Science. The merger of The Scientific Monthly with Science at the beginning of 1958 allowed DuShane and his editorial staff to concentrate on the one journal. During this period he instituted the series of articles entitled "Current Problems in Research", each of which summarized for a general scientific audience the current state of an active field of research. Started also as an important addition to Science was the section entitled "News and Comment", which quickly became the most widely read and useful source of information for scientists about governmental, economic and social actions and forces influencing scientific activities. Under DuShane's editorship, the circulation of Science grew from 32,000 to 76,000 .

During his years as editor, DuShane received a number of invitations to return to a university post. In 1962 one came that he decided he could not decline. Vanderbilt University offered him the triple responsibility of a professorship of biology, chairmanship of the biology department and, in the newly created post of Dean of the Graduate Sciences, responsibility for graduate research and education in the basic sciences, medicine and engineering.

$\mathrm{He}$ was a member of the American Association for the Advancement of Science, the American Society of Zoologists, the American Association of Anatomists, Sigma $\mathrm{Xi}$, and Phi Beta Kappa. He was a consultant to the President's Science Advisory Committee and a member 
of the Board of Trustees of Biological Abstracts. At Stanford he served as president of the local chapters of Sigma $\mathrm{Xi}$ and the American Association of University Professors. $\mathrm{H}_{\Theta}$ is survived by his wife, Susan Elizabeth (White) DuShane, three daughters, and two brothers.

\section{DaEl WOLFLe}

\section{Dr. Don E. Eyles}

Dr. Don E. Eyles died on October 4, 1963, of coronary thrombosis on board ship in Penang, Malaysia, a few hours before ho and his family were due to return to the United States. This suddon death of an outstanding scientist and oxcellent colleague was particularly tragic, as Dr. Eylos was about to retiro after twenty-four years' work for tho U.S. Public Health Service to join the Lahore (Pakistan) Unit of the Institute of International Medicine of the University of Maryland Sehool of Medicine.

Dr. Eyles was born in 1915 in Atlanta, Georgia, and obtained his M.S. (Biology) at Emory University and his Sc.D. at the Johns Hopkins University in Baltimoro.

During the early period of his academic life he was interested in ornithology and medical entomology, but later much of his work was connected with investigations on malaria imported into the United States by returning Service-men, and with curative action of drugs against rolapsing malaria infections. The difference betweon the effect of pyrimethamine and primaquine on the tissue forms of malaria parasites became clear as a result of this work. The curative action of pyrimethamine and sulphadiazine, and the synergistic effoct of these drugs in toxoplasmosis, were roported by Eylos et al. in 1952, and those findings wore promptly confirmed in acute and chronic forms of the disease. Much knowledge of the epidemiology of toxoplasmosis was due to the work of Eyles on the relationship betweon the infection in domestic animals and its transmission to man.

In 1960 Dr. Eyles, taking a clue from his accidental laboratory infection, showed that Plasmodium cynomolgi bastianellii of monkeys can bo transmitted to man through a mosquito. This started much now and still expanding research on the possibility of simian malaria as an anthropozoonosis.

In 1961 Dr. Fyles was given the task of establishing a research unit of the U.S. Public Hoalth Service in Malaya and he went to the Far East accompanied by his wife and three children. The research unit was set up at the Institute for Medical Research in Kuala Lumpur and within less than throo years Eyles and his Malaysian, American, British and Australian colleagues producod a remarkable series of investigations which have groatly extended our knowledge of simian malaria. Five now species of malaria parasitos of Malaysian monkeys and of a moose-doer wore discovered and their relationship to a number of anopheline voctors was established.

A new area for further research of considerable funda. mental and practical importance was thus opened in a field that until rocently seemed to be uninspiring and woll-troddon. The impetus given in this way to the investigation of simian malaria was characteristic of Eyles's vision, determination, leadership and phenomenal energy. During the past year Fylos was greatly interested in the problem of resistance of human plasmodia to synthetic drugs and particularly 4-aminoquinolines. Ho left a number of papers which are now awaiting publication.

Somo of us who saw Eyles in September at the International Congresses of Tropical Medicine in Rio de Janeiro and who heard his summary of the work carried out in Malaya could not help saying that he seemed to bo in a hurry to complote one job to start another. He was in a hurry, indoed, for his "appointmont in Penang".

Eylos's work resulted in more than a hundred publica. tions. Ho has demonstrated his qualities as an administrator of a research laboratory and his brilliance and versatility as an investigator of general and specific problems in parasitology. One of Eyles's most important assets was his ability to work with a toam; he has undoubtedly stimulated in others as much research as he has been personally responsible for. His proficiency in experimental work in parasitology was equalled by his general knowledgo of ornithology, botany and entomology. $\mathrm{He}$ was an intensely live individual-an inveterate collector of almost anything, biological or otherwiseuniversally liked and admired by those who have had the good fortune to know him during his short, happy and fruitful life.

L. J. BRUCE-ChwatT

\section{Mr. Douglas P. R. Petrie}

Douglas Petrie died at his home suddenly on Octobor 13, aged fifty-two. He was born in Australia, graduated in Melbourne in 1931 in physics, took his M.Sc. under the late Prof. Laby two years later, having worked on X-ray vacuum spoctroscopy and on this gained an 1851 Exhibition Overseas Scholarship which he hold in the Cavendish Laboratory. Here he worked with Dr. M. L. E. (now Sir Mark) Oliphant, devoloping the electron optics for a hydrogen ion gun and for a very high voltage discharge tube, one of the first essays in electrostatic focusing to be performed on ion accelorators. He was awarded the M.Sc. for this work.

In October 1937, he joined the research staff of the Valve Department of Standard Telephones and Cables, Itd. Like most of this staff, ho was soon brought into the development of decimotre- and centimetro-wave oscillators for airborne radar sets and worked on this throughout the War. Potrie's groat physical and mathematical skill played an extremoly important part in tho devolopment of prartical continuous-wave oscillators for various wave-lengths from $6-20 \mathrm{~cm}$ which wero used for a variety of operational and instrumental purposes. The development of these required much detailed calculation of the distribution of high-frequency electric fiolds. Ho discovered and proved a now thoorem in electrostaties, which made it possible to replace intelligent guessing by accurate quantitative design.

Little of his war-time work could be published at the time it was performed, but at the end of the War he collaborated with other members of the team to write a major paper on the principles of velocity-modulation which received the Institution of Electrical Engineers Radio Section premium award for 1946-47.

After the War he joined the Associated Electrical Industries Research Laboratory as a section loader, jointly with I). D. R. Chick, to develop the Company's interests in nuclear physics, and together they were responsible for designing and constructing a $4-\mathrm{MoV}$ electrostatic generator operating under high gas pressure, it being the Company's intention to exploit the patents of Dr. van de Graaff in Great Britain under licence. The construction and use of the machino served to train the first genoration of scientists in Associated Electrical Industries for the coming nuclear power developments, but in addition very many now ideas were incorporated into this machine, in particular, Petrie's experionce of ion focusing. Before the idea of tandem generators had been developed, Petrio and Dr. Chick in 1948 began the investigation of a helical slow-wave structuro to accelorato ions emerging from the van do Graaff generator then boing built, and, with others, he designed and constructed a pilot length of 1 metre, into which $2 \cdot 5-\mathrm{MeV}$ protons were injected and accelorated successfully to $4 \mathrm{MeV}$. This would cortainly have been continued but for the proved success of the tandem generator, the first of which to be built by the Associated Electrical Industries incorporated a number of significant improvements due to Potrie.

Petrie then turned to electron optics and took charge of the Section dealing with this subject. He developed 